九州大学学術情報リポジトリ

Kyushu University Institutional Repository

Bryan Lowe. Ritualized Writing: Buddhist Practice and Scriptural Cultures in Ancient Japan. University of Hawa i "i Press (Kuroda Institute), 2017.

Hsueh Shirai, Yoko

https://doi.org/10.5109/2231588

出版情報: Journal of Asian Humanities at Kyushu University. 4, pp.95-100, 2019-03. Kyushu University, School of Letters, Graduate School of Humanities, Faculty of Humanities バージョン:

権利関係 : 


\title{
Bryan Lowe. Ritualized Writing: Buddhist Practice and Scriptural Cultures in Ancient Japan. University of Hawai'i Press (Kuroda Institute), 2017.
}

\author{
BOOK REVIEW BY YOKO HSUEH SHIRAI
}

$\Delta$ FASCINATING investigation into a hard-to-access trove of paper documents written over a millennium ago, Bryan Lowe's first book, Ritualized Writing, is unexpectedly refreshing and reader-friendly-especially for those with a fundamental grasp of the historical setting of Nara-period Japan (710-784) - and will generate much excitement in multiple fields of study. Gaining access to the primary documents originally stored within the Shōsoin repository, part of the Buddhist temple complex of Tōdaiji located in the modern-day city of Nara, is a challenge in itself. To further complicate matters, scholars like Lowe focus on what was written during the eighth century on the reverse side (verso) of already-used paper-scrap paper-an instance of government officials reusing a valuable, handmade commodity for administrative record-keeping. An accident of history, it seems, led to the reused paper scrolls being stored inside the Shōsōin (p. 24), a wooden storehouse that has miraculously survived centuries of warfare and fires. These writings can be jumbled, and the black ink has frequently seeped from one side to the other, making some of the writing on the verso almost illegible; yet these records inform us about the daily workings of scribes, among others, employed within the eighth-century institutional network that produced these papers.

Although Lowe makes use of modern reprints when necessary (p. xiv), on the one hand his analysis of the ancient documents reveals the great breadth of detailed, literal information based on what was written; on the other hand, he also reads between the lines to offer broader theories, especially with regard to the lives of scribes such as Karakuni no Hitonari, who were not from the highest levels of the social hierarchy and were not included in official chronicles, but nonetheless left behind limited traces of personal history through their workplace duties. And a lot of documentation remains extant: "[Due to] a wealth of manuscript evidence, both in the form of a few thousand extant sutra manuscripts from the late seventh through the early ninth centuries and in more than ten thousand documents detailing the activities of a scriptorium [located at Tōdaiji], early Japan offers unrivaled sources for studying sutra transcription" (p. 7).

According to Lowe's own stated goals, "I should stress that this book is not purely a social or cultural history in the sense of a work that primarily concerns itself with [Buddhist] practice at the expense of doctrines" (p. 7). I agree and also believe this book offers a far-reaching social history of eighth-century Japan, primarily focusing on the Nara capital, that crosses interdisciplinary boundaries. Ritualized Writing has something for just about anyone with an interest in early Japan. My perspective, as an art historian with 
a background in Buddhist icons, occasionally departs from Lowe's and his own field of religious studies, but this does not dampen my enthusiasm for the publication.

Lowe tells us many things, but at its most basic level the core message that essentially drives the narrative might be found in the final page of the epilogue: the Buddhist rituals associated with the copying of scriptures and initially sponsored by the ruling class trickled down the social hierarchy, in particular to scribes who held government jobs and did the actual copying of the Buddhist texts. The texts were inaccessible to all but the most elite social groups, so from their (unglamorous, low-paying) jobs the scribes were able to gain "exposure to traditional refinements," and "in this way, the practices of elite patrons enabled a more diverse participation in Buddhism, and elites and commoners alike shared a common ground made up of ritual practices, cosmological conceptions, and even social organizations [associated with sutra transcription]" (p. 213; see also p. 18). Throughout the book, Lowe builds on his thesis regarding the relationship between patrons and those employed in the service of a patron's projectsthose that hired and those that were hired. My thoughts on such notions appear at the end of this review.

Before proceeding with an outline of each chapter, a final note about the enviable degree of foresight and discipline on display by the author. At a little over twohundred-and-fifty pages, including the appendix and bibliography, the book is pleasantly slim. Lowe was probably able to write a tightly focused, streamlined book because he apparently removed a great deal of research that was not relevant to the book's main thesis, and instead of stuffing this information into footnotes or endnotes, he published separate articles that expand, in considerable detail, on related topics. As we read along, the author directs us to one of his nine articles published between 2011 and 2016 for further details on a specific topic. Lowe's method worked well for me and was in effect quite brilliant.

The introduction sets up the background for this book and discusses a descriptive term often used to label the perceived, dominant historical characteristic of Nara-period Japan, "State Buddhism," or according to Lowe, "state Buddhism." The significance of using a lowercase " $\mathrm{s}$ " reflects a major concern argued repeatedly by the author as he attempts to shift focus away from the directives of a monolithic state documented in official historical annals, and instead seeks to uncover what took place at the level of individual actors, whether as patrons or as scribes. Lowe reacts against "traditional rubrics for understanding Japanese Buddhism, which have focused primarily on the state's patronage and control of the religion" (p. 3; see footnote 32 on p. 14 for references in English on this subject). Especially interesting is his analysis of Inoue Mitsusada 井上光貞 (1917-1983), a leading scholar whose influence remains hard to break, but that is exactly what Lowe attempts; he indicates that Inoue saw parallels between eighth-century Japan, "with its heavy-handed involvement of the state," and Inoue's contemporary life in postwar twentieth-century Japan, "a period that Inoue viewed with retrospective contempt in his published memoirs" (pp. 15-16). According to Lowe, Inoue viewed Nara-period state Buddhism as "an obstacle that needs to be overcome in the name of a liberal project [the 'eventual reform of Buddhism in the Kamakura period (1185-1333)'] that valorizes freedom of religion from state control" (p. 16), much like what Inoue presumably anticipated in the postwar reformation of twentieth-century Japan. Lowe moves away from this model, stating that "Nara Buddhism was far more diverse than the label 'state Buddhism' suggests" (p. 16) and showcases this "diversity" in his book, in particular the idea that Nara Buddhism was not just a political tool used by governing bodies to both unify and consolidate power into a centralized system, but served other purposes and groups-including nonstate affiliated actors - in various ways. The remainder of the introduction provides a wonderful outline and history behind the document cache stored inside the eighth-century Shōsōin repository (pp. 21-26).

Lowe divides the rest of the book in a straightforward manner, three parts with two chapters each, for a total of six chapters. The author's summary of each chapter appears on pages 19-21.

Part one, "Ritual Practices," chapter 1, "Merit, Purity, and Ceremony," informs readers about the three topics appearing in the chapter title, and how writing was ritualized in East Asian Buddhism. Regarding "merit," I found it interesting that in "sutra copying, even hiring others to transcribe a text represented a form of virtuous conduct. Patrons gained merit without lifting a brush" (p. 31) as this "allowed lay Buddhists to fulfill one of their primary moral responsibilities: patronage" ( $p$. 31). "Purity" played a critical role in the transcription process: "Impurely copied works not only threatened the empowerment of the manuscript but could also, in extreme cases, bring death to the scribe" (p. 36). 
Achieving purity required both "bodily practice" and "wholesome mental states" (p. 37), and usually involved avoiding the consumption of meat and alcohol; sexual abstinence; ritual bathing; wearing "pure garments" that were often white clothing; upholding precepts; and transcribing scripture in "sanctified spaces" (p. 38). "Ceremony" was the final step that ensured the proper transfer of merit into the hands of patrons, allowing them the opportunity to announce, celebrate, and dedicate the merit gained from the scripture transcription project. Without a proper dedication ceremony, the "ritual remained incomplete" (p. 50).

Chapter 2, "Ritual Compositions," examines what was announced during the dedication ceremony mentioned in chapter 1 . This involved reading aloud written compositions known as ganmon 願文 (prayer texts) that were "performed in a ritual setting" and "were not purely personal supplications but socially sanctioned literary compositions" (p. 57). Most of chapter 2 explores the literary aspects of ganmon, a "recognizable genre in both medieval China and ancient Japan, and probably the Korean peninsula as well" (pp. 60-61), providing several instances of ganmon with translation and analysis. The authors of ganmon are unknown and Lowe suggests that speechwriters may have been hired, but this did not matter in the eighth century because the "sponsor of the rite becomes the subject of the prayer regardless of who the author [of the ganmon] may have been" (p. 60). In the case of Nara-period Japan, "prayers were most commonly [but not solely] performed on behalf of the deceased, asking that they be born in a better place such as a heaven or a pure land" (p. 61). Lowe proceeds with a compelling discussion about the kinds of pure lands mentioned in the prayer texts. "By the Nara period, patrons were readily conversant in the terminology of pure lands and heavens that had only recently been introduced to Japan, as evidenced [in ganmon]" (p. 74). References were made to Amitābha's realm using a "variety of names" (listed on p. 74), and "perhaps most common were invocations of the future buddha Maitreya's Tușita heaven" (p. 74). Most exciting to me was learning that "patrons creatively imagined the heavens and pure lands they invoked," as in the case of Dōgyō 道行 (n.d.), a monk who led a fellowship group (chishiki 知識) (p. 74). In the prayer, Dōgyō referred to both Amitābha's Land of Bliss and Maitreya's Tușita heaven; in this sense, "creatively imagined" indicates that individuals made up their own wishes that could be unorthodox, such as an odd mixing of sepa- rate entities like Amitābha and Maitreya (see footnote 48 on p. 75 for Chinese precedents and other instances).

Part two, "Organizations," chapter 3, "Writing Societies," addresses fellowship groups or "writing societies" made up of those who joined together to pool resources and jointly sponsor a scripture transcription project; chishiki members "commonly referred to themselves with terms rendered literally as 'wholesome friends' (zen’u 善友) [among other similar terms]" (p. 99). Because individual donor names appear in the documents, scholars discovered that chishiki membership was not limited to aristocrats, and many groups were rooted in specific geographic communities, including villages. In his examination of chishiki located outside the Nara capital, Lowe emphasizes that although these projects were not sponsored by the state, the fellowship groups had to rely on state-funded institutions and staff: those with the requisite skill sets as well as the scriptures needed for copying were not readily available in the private sector. Based on this dynamic, the author highlights the interconnectedness between such nonstate and state projects, drawing particular attention to "straddlers" (p. 85) or individuals that did the connecting by straddling the state and non-state/grassroots organizations. Scribes in the employ of the state submitted official requests for time off to participate in such non-state scripture transcription projects (pp. 134-39). Why would the state approve this? "It appears that personal connections helped patrons secure permission to use the human resources of the [Tōdaiji] scriptorium for private projects" (p. 135), and this makes sense. In this manner, chapter 3 supports Lowe's thesis regarding "state Buddhism" by showing the diffuse, porous nature of the relationship between the state and its people. Before moving on to the next chapter, there is one paragraph on page 87 I wish to clarify since it pertains to my field, but is not especially relevant to the book's main concerns. Regarding the early origins of chishiki, Lowe mentions the "commissioning of images and temples in the capital, as evidenced by... a 623 inscription on an image of Sākyamuni at Hōryūji." Located in present-day Ikaruga-chō, Ikoma-gun, Nara Prefecture, Hōryūji was never situated "in the capital." There is also reference to "inscriptions on a Maitreya image and roof tiles originally from the Kaya temple site in Bitchū province." The "Maitreya image" is the icon housed at Yachūji 野中寺 in the city of Habikino, Osaka Prefecture, and the "Kaya temple site" in Japanese appears to be Kayadera haiji ato 柏寺廃寺跡 in the city of Sōja, 
Okayama Prefecture. Another intriguing monument associated with chishiki, but not mentioned by Lowe, is a pyramidal, mounded earth structure covered by roof tiles inscribed with donor names, known today as Dotō 土塔 and built within the Ōnodera 大野寺 precinct in the city of Sakai, Osaka Prefecture. ${ }^{1}$

Part two, chapter 4, "Instituting Transcription," shifts the focus to the most powerful aristocratic patrons of scripture transcription projects in the Nara capital, Heijōkyō. There is much to unpack here, but much of the focus seems to be centered on highlighting the ambiguous, messy distinctions between the "state" (public) and the most influential "aristocratic households" (private) as staff and funding intermixed or were tangled together (see pp. 142-45). The key players in this chapter were political rivals, Prince Nagaya (676/684-729; see p. 190 for a lineage chart), grandson of a former tennō 天皇 (literally "heavenly sovereign" or more commonly "emperor"; see footnote 33 on p. 69), and Fujiwara no Asukabe-hime or Kōmyōshi (701-760, p. 122), a non-royal who was named $k \bar{o} g \bar{o}$ 皇后 (Queen consort) to Shōmu Tennō (701-756) in 729, as Queen consort Kōmyō. Household estates of the highest-ranking government officials like Prince Nagaya were "granted a staff of administrators from the central government to manage household affairs" (p. 119); his massive estate operated like a mini-state with personal "saddle makers and doctors" (p. 119) as well as a "bureau that managed sutra transcription and image production" (p. 119) that likely involved six or seven scribes holding official state posts and working on a project to copy six hundred scrolls of Buddhist scripture (p. 120). As for Kōmyōshi's household scriptorium, this bureau was appended to the most powerful state temple, Tōdaiji, after she became Queen consort. Described as "likely the most prolific sutra-copying bureau in the Nara period" (p. 122), the scriptorium at Tódaiji served the interests of the Queen consort and appears to have closed its doors after 776 , following the death of Queen consort Kōmyō in 760 and the 770 death of her only surviving child, who reigned twice as Kōken and Shōtoku Tennō (718-770) (pp. 130-34). Chapter 6 also discusses Queen consort Kōmyō and her involvement in scripture transcription projects, but chapter 4 introduces the extent of blurred lines between the public state and private aristocratic

1 Yoshikawa, Shōmu tennō to butto Heijōkyō, pp. 156-67; Sakaishi Kyōiku linkai, Shiseki Dotō: Ikōhen. estates. This chapter also defines scriptoria as a place where scribes "produced mountains of paperwork" ( $p$. 107) on matters both secular and sacred, and is a term used by the author "to refer to primarily lay-administered bureaucratic organizations with ready access to library collections and skilled laborers who copied sutras commissioned by patrons on demand" (p. 107). Lowe includes a step-by-step process of how a scripture transcription project progressed and the length of time required for each step. Scribes were "paid per sheet" (p. 114), for example, and "sat on the floor to copy the text on a low table" (p. 111). Completed sets of copied scriptures were then distributed to selected temples and presumably used during memorial rituals of the deceased person to whom the merit was directed (p. 114).

Part three, "Microhistories," chapter 5, "Disciplinary Regimes," returns to individuals, and in particular the life history or "microhistory" of someone toward the bottom of the social hierarchy: a scribe by the name of Karakuni no Hitonari, who worked at the Office of Sutra Transcription (hereafter, OST) at Tōdaiji. After eight years holding various positions at OST, Hitonari became a Buddhist monk (p. 150). According to Lowe, Hitonari imposed an enormous amount of self-discipline in his daily regime (hence the title of chapter 5) to further his own education, gaining access to texts that would otherwise have been out of his reach (pp. 150 and 168). Self-discipline was likely necessary because the life of a government scribe was not easy: there was "little opportunity for social advancement"; salaries were low; the meals provided by the state lacked nutrition and possibly contributed to disease; and the cramped working conditions led many to submit written requests for "medicinal wine" to ease their physical pain (p. 149). The scribes also "slept at the scriptorium and were only able to return home for vacation once every two or three months" (p. 156), making them virtual prisoners. This made me wonder about scribes who had no aspiration to become Buddhist monks. Was Hitonari an exception? Were individuals like him with a burning desire to read and copy Buddhist scriptures drawn to this job, and thereby more likely to endure harsh working conditions as government scribes? Or was this the standard of living for all low-level government workers in the capital? There might not be enough surviving evidence to answer my questions, but I was intrigued.

Part three, chapter 6, "Haunted by Demons, Watched by Kings," the final chapter, tells the narrative from the 
point of view of those at the top of the social hierarchy, reflecting on possible intentions and agendas behind Queen consort Kōmyō's sponsorship of massive transcription projects. These concerned three sets of scriptures in particular: Scripture on Saving and Protecting Body and Life (hereafter, Scripture on Saving), Golden Light Sutra, and Scripture on Brahma's Spirit Tablets, all copied "from the middle months of 748" (pp. 171-72). Regarding the Scripture on Saving, Lowe mentions that this scripture "has received no attention in any language" (p. 174). Fear of demons and divine punishment for bad deeds were serious and real concerns, effectively shaping policy and practice in Nara Japan. For example, black magic was blamed for a particularly critical event: the death in 728 of Shōmu Tennō's firstborn son with Kōmyōshi, when she was still just one of several consorts. The son was less than a year old at the time of death, and "never before had an infant been formally granted this title [of crown prince]." This indicates to Lowe the "value of this prince ... and the shock that must have accompanied his passing" (p. 191). Buddhist structures established to pray for the deceased prince evolved into the massive Tôdaiji complex during the eighth century, further corroborating the presumed significance of the prince to his family. ${ }^{2}$ Less than six months later, Prince Nagaya (mentioned in chapter 4) was accused of practicing sadō 左道 (black magic), casting curses that led to the crown prince's death (p. 192); Nagaya was then promptly condemned to death. Two decades later, in 748, Princess Abe, the only surviving child of Shōmu Tennō and Queen consort Kōmyō, was named crown princess (p. 193). The "Queen Consort's Palace Agency" shipped over highly valued, fine paper to the scriptorium (OST) at Tōdaiji to "transcribe one hundred copies of [Scripture on Saving]" (p. 171) because this scripture claimed to offer protection against "venom magic" (pp. 199-200), which involved filling a vessel with poisonous creatures that consumed one another. Princess Abe succeeded her father to become tennō in 749, "in a climate filled with uncertainty and potential threats" (p. 194). Lowe informs readers that the Queen consort sought protection for her daughter against demonic threats via scripture transcription projects because "Princess Abe would need all the help she could get" (p. 195).

The epilogue reaffirms notions from the book, such

2 Morimoto, Tōdaiji no naritachi, pp. 2-25. as "Early Japanese Buddhism cannot be understood in terms of clearly demarcated and static social groups," and "social organizations and institutions, beliefs and practices ... transcended social class" (p. 212). While persuasively argued, to erase class lines like this in Nara Japan sounds extraordinarily bold and contemporary, and contrasts sharply with the standard Japanese scholarship; however, for Lowe to venture into unfamiliar, uncharted territory does not disqualify the essence of his thesis. A seed has been planted in my mind, and I will continue to ponder the significance and meanings of Lowe's subtly radical scholarship.

Ritualized Writing offers a wealth of new ideas, and here are a few more to consider. First, scripture transcription is an act of replication, not the creation of a new or original work; there are many parallels from the study of Buddhist icon production, primarily based on the concept that a faithful copy is more authentic to the true image of a buddha. ${ }^{3}$

Second, Lowe presents a convincing picture of the Nara state's porous, hard-to-define nature, one that is rather messy, with blurred distinctions like those between "public" and "private" as well as "secular" and "sacred." On this point, Lowe explains that "the concept of 'secular' as completely divorced from 'religion' did not even exist" (p. 172) during the Nara period. My perspective of the Nara state includes an image of a huge, relatively efficient bureaucracy whose scale of force was newly enabled by fairly high literacy rates for the first time on the Japanese archipelago. This allowed the state and its institutions to maximize tax revenues from village units under its jurisdiction and to initiate monumental construction projects. Economic history as documented in the Shōsōin collection may not have been especially relevant to this book but was a major concern for the Nara state.

Third, Lowe's terminology, or more broadly, word choice, was at times puzzling and potentially misleading in a few, isolated examples. It would have been helpful if the author had defined basic yet key terms in English at first mention, such as "scriptorium" (which appears on the first page but is not defined until page 107) or "colophon." I wondered, for example, about the specific meaning of "scriptorium," and whether it ap-

\footnotetext{
3 A useful note about replication traditions in East Asia appears in McCallum, Zenkōji and Its Icon, footnote 4, p. 213; see also pp. $180-84$.
} 
plied only to the building itself, or included conditions such as a certain number of scribes, was restricted to only religious texts, or possibly served to copy secular documents, and so on. On a separate point, somewhat distracting was the inconsistency in names given to the modern countries of China, Korea, and Japan. In the eighth century, China was called Tang and Korea was dominated politically by the Silla Kingdom; questions remain about the name of the Japanese islands. When Lowe writes about "tales circulating in China, Silla, and Japan" (p. 46; also see p. 53), it is unclear why he lists "Silla" and not "Korea." Also, "in both medieval China and ancient Japan, and probably the Korean peninsula as well..." (pp. 6o-61), why is there no mention of "ancient Korea"? Or "Japanese archipelago" to match "Korean peninsula" instead? Finally, a different set of issues relates to the challenge of translating nouns from the Japanese original to English equivalents.

In the case of the scriptorium at Tódaiji, the author carefully lists chronological shifts in the Japanese name and the location of the scriptorium that served Queen consort Kōmyō (pp. 122-34). The modification in name closely follows changes in authority or the political status of its main patron, as "institutional structures [and their names] changed in accord with political realities" (p. 127). So when an institution's funding sources increased or decreased in connection with shifting political fortunes due to power struggles, immediate adjustments were made to staff numbers, place of operation, and official name. Since I had not paid much attention to this phenomenon until reading Lowe's book, I became curious about another institution mentioned by the author, "Queen Consort's Palace Agency." This institution appears in the index under various subcategories but without reference to its name in the Japanese primary sources, although footnote 49 on page 124 offers further readings in the Japanese secondary literature. As it turns out, a change in this powerful office's name - primarily known as shibichūdai 紫微中台 and $k \bar{o} g \bar{o} g \bar{u}$ shiki 皇后宮職—was directly tied to critical and complicated political developments. ${ }^{4}$ Providing an English translation of an institution's name appears deceivingly simple, but, as here, underscores the many challenges Lowe faced in his study of ancient docu-

4 For definitions in English of shibichūdai, see Piggott, The Emergence of Japanese Kingship, pp. 269 and 324, and for kōgōgūshiki, p. 316; discussion of these terms and their significance appear throughout Piggott's book. ments. And when I encountered gaps in my knowledge of Nara-period institutional, social, and religious history during my reading, I was enticed to learn more, beyond the interests of this book.

Ritualized Writing reminds me of the joy I felt after turning the final page of Carlo Ginzburg's The Cheese and the Worms: The Cosmos of a Sixteenth-Century Miller (Johns Hopkins University Press, 1980). This is no coincidence, as Lowe informs readers that he proceeded in "accord with the approach of the famed microhistorian Carlo Ginzburg" (p. 169). The scribe Hitonari was Lowe's counterpart to Ginzburg's miller - an indicator of what was happening in the margins, in the shadows of the lineage groups that controlled the state and its institutions. While much remains unknown about Nara Japan and how life was actually lived, for those of us who have trouble mastering the primary documents, Lowe's study will get us closer. The secondary Japanese scholarship examining these materials often focuses on extremely narrow topics and are highly technical studies that address mostly specialist concerns. Lowe's new addition to the field is an even more welcome contribution because his own brand of methodology departs from such specialized, technical writings in Japanese. Instead, he offers a broader, more comprehensive synthesis without sacrificing the attention to detail that can be found only through a close reading of the primary documents. Moreover, his accessible and lively writing style captivates the reader and makes his task seem easy, almost inviting me to challenge myself and attempt to read the corpus of primary documents from the Shōsōin. But I know better, and eagerly await the author's next book.

\section{Reference List}

McCallum, Donald. Zenkōji and Its Icon: A Study in Medieval Japanese Religious Art. Princeton University Press, 1994. Morimoto Kōsei 森本公誠. Tōdaiji no naritachi 東大寺のな りたち. Iwanami Shoten, 2018.

Piggott, Joan. The Emergence of Japanese Kingship. Stanford University Press, 1997.

Sakaishi Kyōiku Iinkai Shōgai Gakushūbu Bunkazaika 堺 市教育委員会生涯学習部文化財課, ed. Shiseki Dotō: Ikōhen 史跡土塔: 遺構編. Sakai: Sakaishi Kyōiku Iinkai, 2007.

Yoshikawa Shinji 吉川真司. Shōmu tennō to butto Heijōkyō 聖武天皇と仏都平城京. Kōdansha, 2011. 